\title{
基礎底面の絶縁と複合改良地盤の埋込み効果による 地震応答低減に関する基礎的研究 FUNDAMENTAL STUDY ON EARTHQUAKE RESPONSE REDUCTION \\ OF BASE ISOLATED SPREAD FOUNDATION WITH BACKFILLED BY IMPROVED COMPOUND GEO-MATERIAL
}

\author{
宮本裕司 ${ }^{*}$, 島村 淳**, 藤井 達***, 星澤府美子 $* * *$, 柏 尚稔***** \\ Yuji MIYAMOTO, Atsushi SHIMAMURA, Satoru FUJII, \\ Fumiko HOSHIZAWA and Hisatoshi KASHIWA
}

\begin{abstract}
This paper addresses the developing of spread foundation surrounded with improved soil which reduces the response of the superstructure. The mechanical properties of the improved compound soil are investigated by laboratory tests. Then earthquake response behaviors of model structures are discussed with various contact conditions at the foundation bottom and different improved backfill soil around foundation by shaking table tests. Furthermore analysis results by 3D-nonlinear FEM are also discussed to clarify the effect of the contact conditions at the foundation bottom and the improved compound soil to seismic response of building.
\end{abstract}

\author{
Keywords: Nonlinear Soil-structure Interaction, Seismic Isolated Foundation, Improved Compound \\ Geo-material, Shaking Table Test, 3D-FEM \\ 非線形相互作用，絶震基礎，複合改良地盤，振動台実験，3D-FEM
}

\section{1.はじめに}

建物の基礎底面と地盤間の非線形相互作用や基礎の埋込夕効果が, 上部構造の地震被害低減に大きな影響を与えることが指摘されてい る 1) 3)。本研究では, 地震応答を低減する構造として, 建物基礎と 地盤間で生じる相互作用すなわち地震力の授受において，基䃈底面 と支持地盤間の摩擦を小さくし絶縁に近い状態にすることで，基礎 入力動の低減と非（避）共振化を目指寸。さらに加えて基礎側面に 勒性のある複合改良地盤を用いることで, 塑性化による震動エネル ギーの吸収と基礎変位を抑制する基礎絶震構造の開発を目的とする。 埋込みによる基礎側面地盤は建物の挙動を拘束し, 震動エネルギ 一を吸収, 逸散させることにより建物の応答を低減させる。しかし, 埋込み地盤の材料物性や非線形特性の不確かさなどにより，その効 果を適切に評価し影響度を確かなものにすることは難しい。ここで 用いる基礎側面地盤は，近年，耐震対策に多く採用されているセメ ント系改良地盤では, 強度の増加にともない脆性的な特性を示し, 耐震性能が低下寸ることが指摘されているため ${ }^{4)}$ ，これらを改良す るためゴムチップと䋊維材を混合した複合改良地盤である。ゴムチ ップの添加による剛性の可変性や変形性能の向上に加え, 繊維材の 添加により勒性の向上を目指したものである 5),6)。また，基礎底面
の絶縁方法としては，支持地盤と基礎底面の間に大変形時に剛性が 低下し，減衰が大きくなる非線形特性をもつ地盤材料 7),8)を用いる ことや，摩擦をできるだけ小さくした合金材を敷きすべり現象を生 じさせることや，鉛直支持力を保持して水平方向の地震力を極力伝 達しないようにするす心゙り支承の設置, さらに将来的な技術として 強磁場での磁気力等による基礎浮上を考えている。このように，基 礎の側面地盤に大変形時にも勒性があり力学特性の明らかな改良地 盤と，基礎底面に絶縁機構を施し地震入力と建物応答を低減できれ ぼ地震被害の軽減に有効な基礎構造となる。

本報では, このような基礎絶震構造を開発する基礎研究として, まず直接基礎の埋込みに用いる複合改良地盤の室内試験（一軸圧縮 試験，繰返し単純せん断試験）により本材料の物性を把握した。次 に，本複合地盤材料を基礎側面の埋土地盤へ適用し，基礎底面と支 持地盤の接触条件を変えた建物模型の振動台加振実験を行った。基 礎底面の接触条件として, 支持地盤に接着させた場合，接着させな い場合,ネオジウム磁石により完全に絶縁した場合を考えた。また， 3 次元非線形有限要素法を用いた解析検討を行うことにより，基礎 底面の接触条件と基礎側面に複合改良地盤を用いた基礎構造の地震 応答低減効果について検討を行った 9, 10)。

\footnotetext{
* 大阪大学大学院工学研究科地球総合工学専攻 建築工学部門 教授・工博

** ケミカルグラウト(侏技術本部技術開発部 課長代理·博士 (工学)

*** (制大林組技術研究所

(元 大阪大学大学院工学研究科 大学院生) 大阪大学大学院工学研究科地球総合工学専攻 建築工学部門 大学院生

***** 大阪大学大学院工学研究科地球総合工学専攻 建築工学部門 助教・博士 (工学)

Prof., Dept. of Architectural Eng., Div. of Global Architecture, Graduate School of Eng., Osaka Univ., Dr. Eng.

Senior Eng., Eng. Development Dept., Chemical Grouting Co., Dr. Eng.

Technical Research Institute, Obayashi Corporation, M. Eng.

Graduate Student, Dept. of Architectural Eng., Div. of Global Architecture, Graduate School of Eng., Osaka Univ.

Assist. Prof., Dept. of Architectural Eng., Div. of Global Architecture, Graduate School of Eng., Osaka Univ., Dr. Eng.
} 


\section{2. 複合改良地盤の室内試験}

\section{1. 複合改良地盤の概要}

本研究では, 建設現場発生土を利用した固化処理土（セメント系 改良地盤, 以下「PL」), 固化処理土に廃タイヤリサイクル品である 廃タイヤゴムチップと繊維材（ナイロン系短繊維）を混合した複合 改良地盤（以下，「TR」）, 固化処理土に高減衰ゴム（ブチル系高減 衰ゴム) を破砕した高減衰ゴムチップと繊維材を混合した複合改良 地盤（以下，「HDR」）について室内試験(一軸圧縮試験, 繰返し単 純せん断試験)を行い，地盤特性の確認を行った。

複合改良地盤（TR，HDR）とセメント系改良地盤（PL）に使用 する各材料の物性を表 1 に示す。泥土は建設発生土で, これに加水 および砂分調整を行い, 一般的な固化処理土で用いられている性状 と一致させた。ゴムチップは, 廃タイヤを破砕した粒径 1〜 $5 \mathrm{~mm}$ の リサイクル品とブチル系高減衰ゴムを粒径 $5 \mathrm{~mm}$ 以下に破砕したも のを使用した。繊維材には, 長さ $30 \mathrm{~mm}$ 程のナイロン系繊維を使用 した。また，固化材は，高炉セメントB種を用いた。

室内試験は, 表 2 に示す 3 種類の配合について行った。セメント 添加量はベースとなる固化処理土(セメント+泥土) $1 \mathrm{~m}^{3}$ あたり $75 \mathrm{~kg}$ に一定として，ゴムチップの添加量を $0,300 \mathrm{~kg}$, 繊維材添加量を 練り上がり全体量の $0 ， 5 \%$ と変化させた材料特性の把握を行った。

\section{2. 試験方法}

\section{（1）一軸圧縮試験}

一軸圧縮試験は, 表 2 に示した配合 No.1〜3 について, 材齢 28 日の水中養生を行った直径 $50 \mathrm{~mm} \times$ 高さ $100 \mathrm{~mm}$ の円柱供試体を用 い, ひずみ速度 $1 \% / \mathrm{min}$ にて実施した。また, 結果の整理について は, 最大圧縮応力点 $\left(\mathrm{q}_{\mathrm{u}}\right)$ を破壊点, その時のひずみを破壞ひずみ （８ｆ）と定義した。ベディングエラーにより応力ーひずみ曲線の初 期部に変曲点が生じる場合については, 変曲点以降の直線部を延長 し，ひずみ軸との交点を破壊ひずみ算出の修正原点とした ${ }^{11}$ 。

\section{（2）繰返し単純せん断試験}

広範囲のひずみ域 $(0.001 \% \leqq \gamma \leqq 10 \%$ 程度) での変形特性を確認 する繰返し単純せん断試験は, 配合 No.1〜3について, 材齢 28 日 の水中養生を行った直径 $100 \mathrm{~mm} \times$ 高さ $30 \mathrm{~mm}$ の円柱供試体をリン グで拘束して実施した $\left.{ }^{12}\right)$ 。供試体は一定の上載圧 $\left(\sigma_{\mathrm{v}}=0.1 \mathrm{~N} / \mathrm{mm}^{2}\right)$ で圧密終了後, 各載荷段階の試験中は上載圧一定, 非排水の条件の 下で行った。入力波は正弦波として 11 波入力し, 応力制御, 一部 ひずみ制御（No.1， $\gamma>1 \%$ ）にてせん断ひずみ $\gamma=10 \%$ 程度まで行 った。入力波の振動数は，0.1，1.0, $3.0 \mathrm{~Hz}$ の 3 ケースを選択した。 なお，結果の整理に際して， $\gamma=0.001 \%$ 付近のせん断剛性 $(\mathrm{G})$ の 值を初期せん断剛性 $\left(\mathrm{G}_{0}\right)$ と定義した。

\section{3. 試験結果}

\section{（1）一軸圧縮試験}

図 1 に応力 $(\sigma)$ とひずみ $(\varepsilon)$ の関係を示す。通常のセメント 系改良地盤である No.1（PL）は，脆性の著しい応力ーひずみ関係 が認められ，破壊ひずみが $1 \%$ 程度で，それを超えると写真 1 (a)の ように脆性的に破壊した。しかし, 廃タイヤゴムチップと䋊維を混 合した複合改良地盤（No.2, TR）, 高減衰ゴムチップと緎維を混合 した複合改良地盤（No.3，HDR）は，破壞ひずみが 7.5\%程度と増 加し, ピーク強度を示した後のひずみ域における強度低下が小さく, 15\%以上変形させても写真 1 (b)，（c）のように形状を保持していた。
表 1 使用材料

\begin{tabular}{|c|c|}
\hline 材 料 & 性状 \\
\hline セメント & $\begin{array}{c}\text { 高炉セメント B 種* } \\
\text { 密度 : } 3.04 \mathrm{~g} / \mathrm{cm}^{3}\end{array}$ \\
\hline 泥土 & $\begin{array}{l}\text { 現場発生土 }+ \text { 加水 } \\
\text { 密度 : } 1.50 \pm 0.02 \mathrm{~g} / \mathrm{cm}^{3} \\
\text { 砂分率** : } 40 \pm 2.5 \% \\
\text { スランプフロー值*** : } 400 \pm 50 \mathrm{~mm}\end{array}$ \\
\hline ゴムチップ & $\begin{array}{l}\text { a) 廃タイヤゴムチップ } \\
\text { 廃タイヤリサイクル品 } \\
\text { 密度 : } 1.1 \mathrm{~g} / \mathrm{cm}^{3} \\
\text { 粒径 : } 1 \sim 5 \mathrm{~mm}\end{array}$ \\
\hline & $\begin{array}{l}\text { b) 高減衰ゴムチップ } \\
\text { ブチル系高減衰ゴム } \\
\text { 密度 : } 1.1 \mathrm{~g} / \mathrm{cm}^{3} \\
\text { 粒径 : } 5 \mathrm{~mm} \text { 以下 }\end{array}$ \\
\hline 繊維材 & $\begin{array}{l}\text { ナイロン系短繊維 } \\
\text { 長さ: } 30 \mathrm{~mm} \text { 程 }\end{array}$ \\
\hline
\end{tabular}

*JIS R $5211 *$ *簡易砂分計による砂分率 ***JHS 313-1992

表 2 改良地盤の配合

\begin{tabular}{|c|c|c|c|c|}
\hline & $\begin{array}{l}\text { No.1 } \\
\text { (PL) }\end{array}$ & $\begin{array}{l}\text { No.2 } \\
\text { (TR) }\end{array}$ & $\begin{array}{c}\text { No.3 } \\
\text { (HDR) }\end{array}$ \\
\hline セメント & {$\left[\mathrm{kg} / \mathrm{m}^{3}\right]$} & 75 & 75 & 75 \\
\hline 廃タイヤ & {$\left[\mathrm{kg} / \mathrm{m}^{3}\right]$} & 0 & 300 & 0 \\
\hline ゴムチップ & [\%] & 0 & 27 & 0 \\
\hline 高減衰 & {$\left[\mathrm{kg} / \mathrm{m}^{3}\right]$} & 0 & 0 & 300 \\
\hline ゴムチップ & {$[\%]$} & 0 & 0 & 27 \\
\hline 繊維材 & [\%] & 0 & 5 & 5 \\
\hline 密度 & {$\left[\mathrm{g} / \mathrm{cm}^{3}\right]$} & 1.54 & 1.38 & 1.38 \\
\hline
\end{tabular}

\section{（2）繰返し単純せん断試験}

図 2 に各配合のせん断岡性（G）と減衰定数（h）のひずみ依存性 を示す。せん断剛性は，各配合ともひずみの増加にともない，せん 断剛性が減少する。通常のセメント系改良地盤である No.1 (PL) は, 初期せん断岡性が $75 \mathrm{~N} / \mathrm{mm}^{2}$ であるのに対して, 廃タイヤゴム チップと繊維を混合した複合改良地盤（No.2，TR），高減衰ゴムチ ップと繊維を混合した複合改良地盤（No.3，HDR）はそれらの混合 により初期せん断岡性が $30 \mathrm{~N} / \mathrm{mm}^{2}$ 程度と小さくなる。なお，本実 験範囲（振動数 $0.1 \sim 3.0 \mathrm{~Hz}$ ）では，すべての配合において，加振 振動数のせん断岡性一の影響はほとんどみられなかった。

減衰定数 (h) は, 各配合ともひずみの増加にともない増加する。 No.2（TR）と No.3（HDR）の複合改良地盤では，減衰定数が超大 ひずみ（ $\gamma=10 \%$ 付近）で約 15\%であった。なお，No.1の $\gamma>1 \%$ で 減衰定数の急激な増加がみられるが，これは，供試体がせん断破壊 を起こしたためである。また，本実験範囲（振動数 $0.1 \sim 3.0 \mathrm{~Hz}$ ） では, すべての配合において, 加振振動数が減衰定数に与える影響 はほとんどみられなかったが，より高い振動数域での減衰特性の把 握は今後の課題である。 


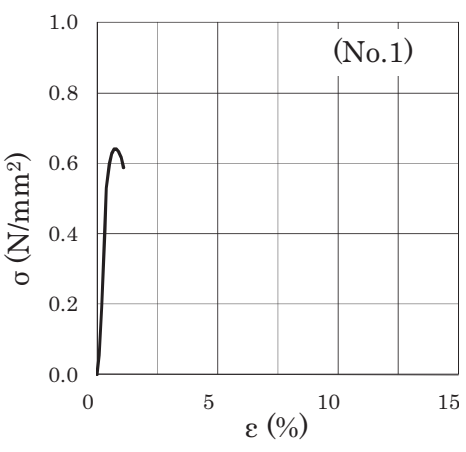

(a) No.1 (PL)

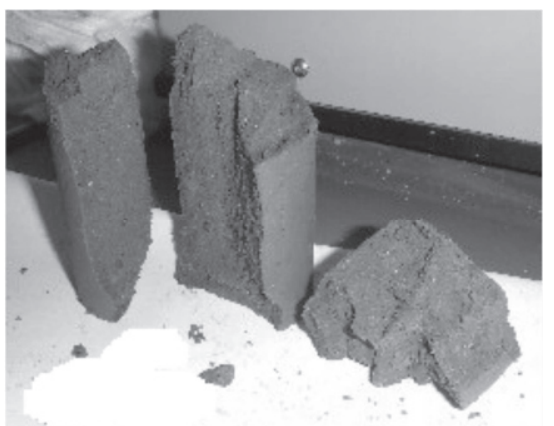

(a) No.1 (PL, $\varepsilon<2 \%)$

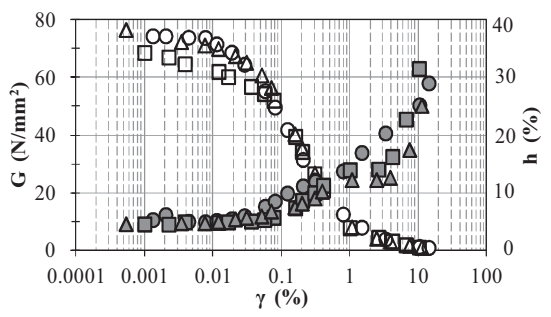

(a) No.1 (PL)

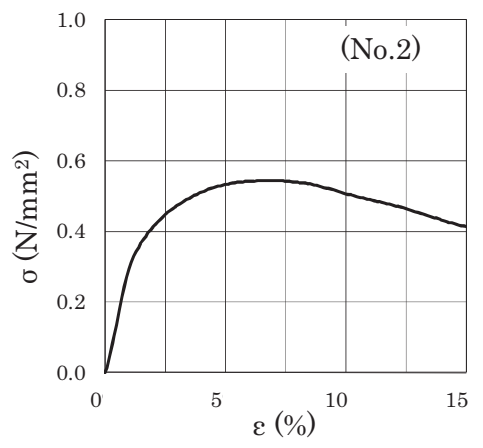

(b) No.2 (TR)

図 1 応力ーひずみ曲線

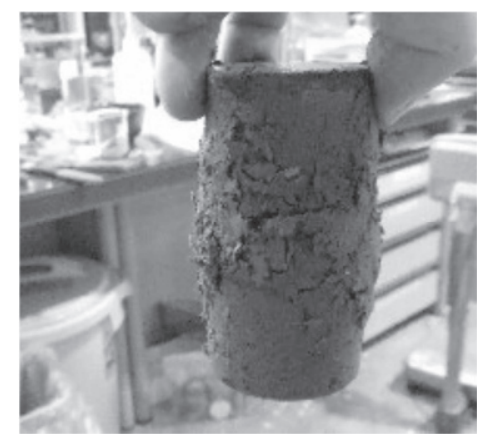

(b) No.2 (TR, $\varepsilon>15 \%)$

写真 1 一軸圧縮試験後の供試体

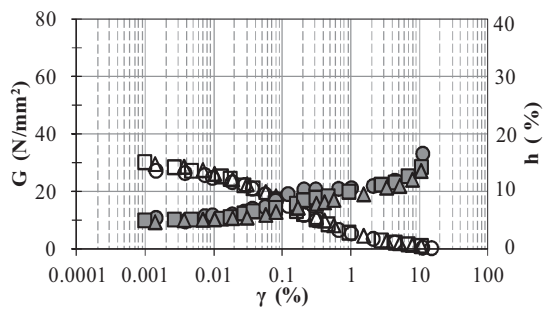

(b) No.2 (TR)

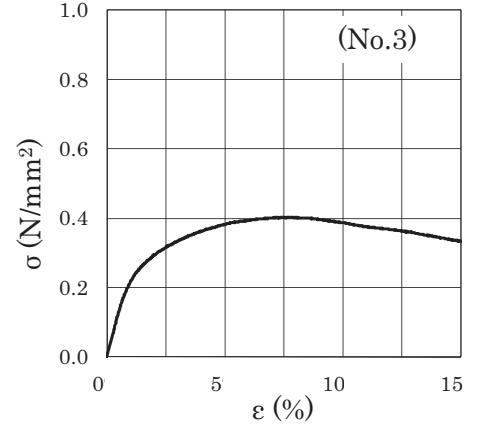

(c) No.3 (HDR)

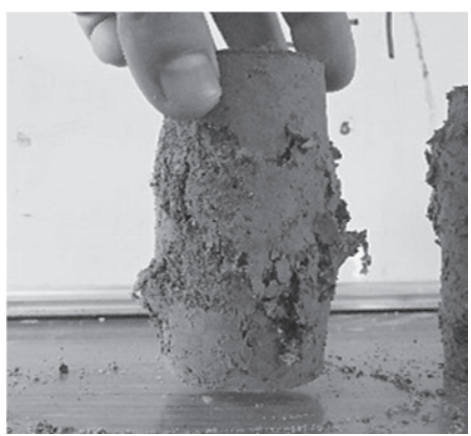

(c) No.3 (HDR, $\varepsilon>15 \%)$

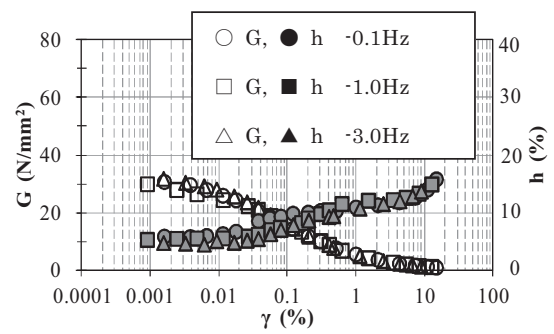

(c) No.3 (HDR)

図 2 せん断剛性 $(\mathrm{G})$, 減衰定数（h）のひずみ依存性

\section{3. 振動台実験}

本実験では, 直接基礎建物の基礎側面埋土地盤の違いと, 基礎底 面と支持地盤（ $\mathrm{Vs}=200 \mathrm{~m} / \mathrm{s}$ 程度）との接触条件の違いによる建物の 地震応答の違いを $1 \mathrm{G}$ 場における振動台模型実験にて検討した。な お，本実験では想定する実物スケールに対する模型の相似比 ${ }^{13), 14)}$ は表 3 の通りとした。また, 加振実験では時間軸を $1 / 10$ としたが、 後述の実験結果は時間軸を 10 倍して示している。

表 3 相似比

\begin{tabular}{|c|c|c|}
\hline 諸元 & 次元 & 相似比 $($ 模型/実物) \\
\hline 長さ & $\mathrm{L}$ & $1 / 100$ \\
\hline 質量 & $\mathrm{M}$ & $1 / 1,000,000$ \\
\hline 時間 & $\mathrm{T}$ & $1 / 10$ \\
\hline 加速度 & $\mathrm{LT}^{-2}$ & $1 / 1$ \\
\hline 密度 & $\mathrm{ML}^{-3}$ & $1 / 1$ \\
\hline
\end{tabular}

\section{1. 振動台実験の概要}

図 3 に実験モデルの平面図と断面図を示す。長さ $600 \mathrm{~mm} \times$ 幅 $400 \mathrm{~mm} \times$ 高さ $250 \mathrm{~mm}$ の鋼製土槽内に，セメント系改良地盤（PL） と同様の配合で支持地盤（Vs=200m/s 程度）を作製した。埋土地盤 は深さ $30 \mathrm{~mm}$, 厚さ $30 \mathrm{~mm}$ として基礎側面に設置した。加速度計は, 建物模型頂部, 基礎上部, 支持地盤上部（地表面），土槽底板に設置 した。建物模型は剛体モデルと板ばねモデルの 2 種類で総重量 $21.5 \mathrm{~N}$ であり，建物上部と下部は真鍮製（密度 $8.4 \mathrm{~g} / \mathrm{cm}^{3}$ ), 基礎部 はアルミニウム製（密度 $2.7 \mathrm{~g} / \mathrm{cm}^{3}$ ) である。柱部は剛体モデルは鉄 製（密度 $7.9 \mathrm{~g} / \mathrm{cm}^{3}$ ), 板ばねモデルは真鍮製で基礎固定時の固有振 動数は $67.2 \mathrm{~Hz}$ である。図 4 に剛体モデルの平面図と側面図を示す。

\section{2. 基礎側面埋土地盤の種類と基礎底面の接触条件}

基礎側面の埋土地盤の違いによる建物応答を検討するため, 埋土 地盤は, 砂地盤（S） とセメント系改良地盤（PL）および，2 種類 の複合改良地盤（TR, HDR）を用いた。さらに, 比較対象として 埋土地盤がない場合（埋込みなし）の計 5 種類とした。なお, 砂地 


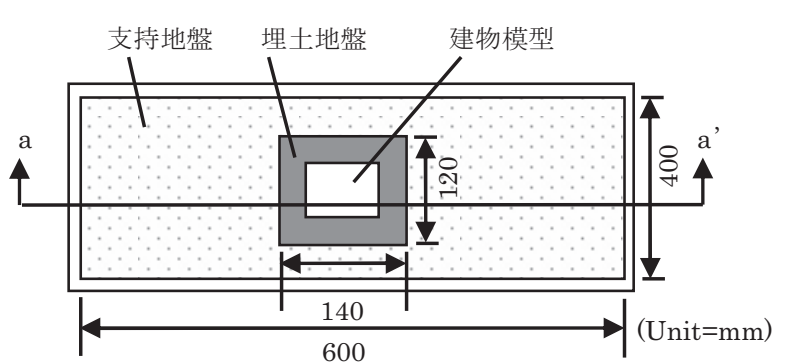

(a) 平面図

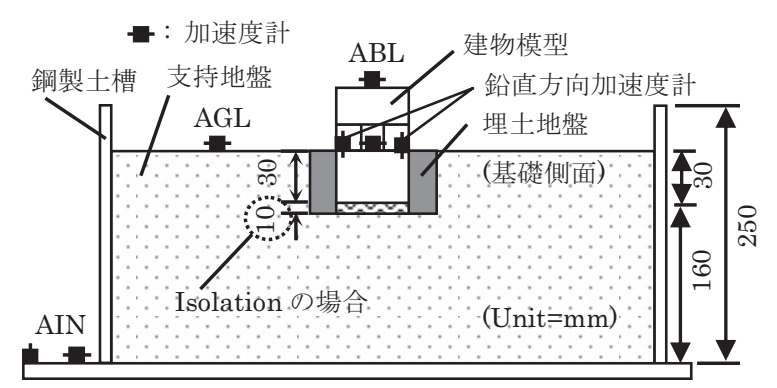

(b) a-a'断面図

図 3 実験モデル

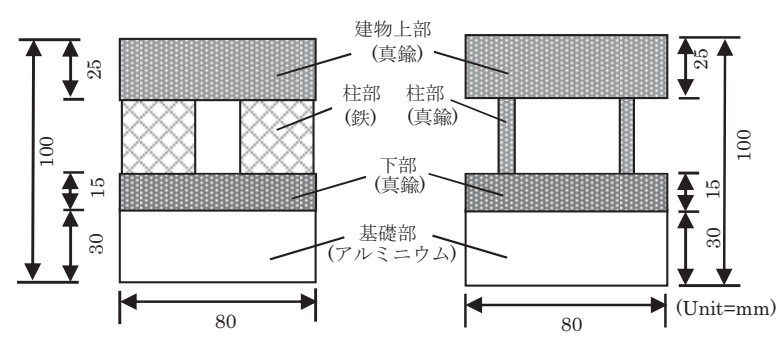

(a) 平面図

(b) 側面図

図 4 建物模型

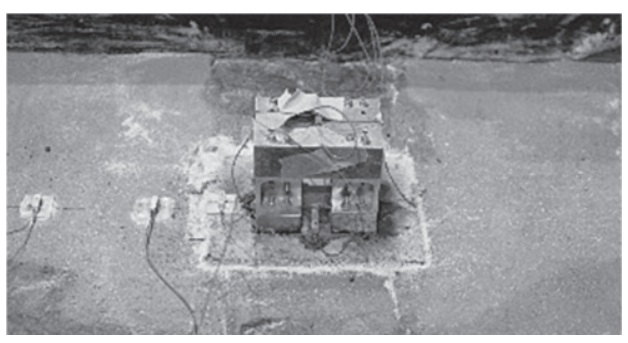

(a) 実験モデル

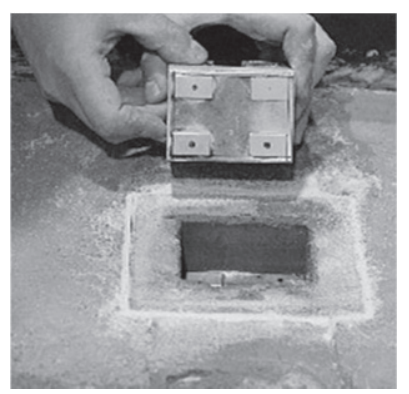

(b) 基礎底面

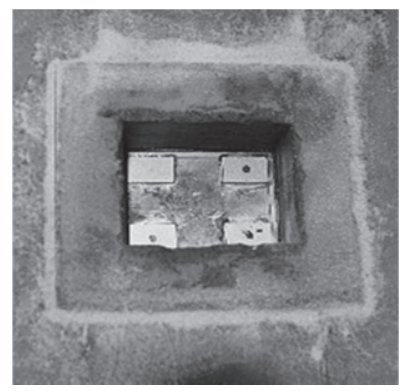

(c) 支持地盤
写真 2 実験モデルとネオジウム磁石設置状況
盤は豊浦砂を用いて締め固めた。

基礎底面と支持地盤の接触条件は，まず，密着状態を再現するた め，基礎底面をエポキシ樹脂にて接着した場合（「Non-slip」)，加振 が大きくなることによる滑り現象を再現するため, 基礎底面を接着 しないで支持地盤上にそのまま置いた場合（「Slip」），さらに，基礎 底面と地盤を絶縁し, 摩擦が無い状態を再現するため, ネオジム磁 石で基礎底面を $10 \mathrm{~mm}$ 浮かした場合（「Isolation」（写真 2)）につ いて, これらの Non-slip, Slip, Isolation の計 3 種類の接触条件で 実験を行った。

\section{3. 入力地震動}

実験で用いた入力地震動は, 図 5 に示す最大加速度が $386 \mathrm{gal} の$ 告示波 JMA 神戸（1995NS）位相である。入力レベルは，加速度の 振幅を $1 / 5$ 倍 (「小加振」)， 1 倍 (「大加振」), 1.5 倍, 2 倍と変化さ せ，時間軸を $1 / 10$ に縮尺し，水平一方向加振で実験を行った。

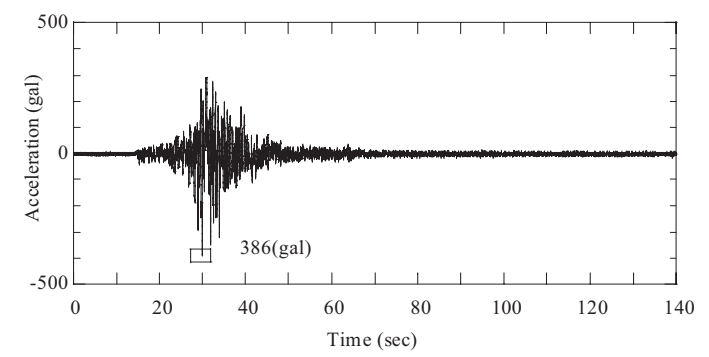

図 5 加速度時刻歴波形（告示波 JMA 神戸位相）

\section{4. 実験結果}

\section{（1）最大加速度による比較}

剛体モデルの建物上部（ABL）と地表面（AGL）の加速度時刻歴 波形の最大值を比較した。ここでは，基礎底面の接触条件が，接着 ありの場合（Non-slip），接着なしの場合（Slip）を図 6 に示す。

Non-slip の場合は, 埋込みがない場合と埋込みが砂地盤（S）で ある場合に最大加速度が増幅していることから，低拘束圧下となる 砂地盤では埋込み効果が発揮できていないことがわかる。これに対 して, 側面にセメント系地盤（PL）や複合改良地盤（TR, HDR） を用いた場合には増幅が小さい結果となっている。

Slip の場合は, 埋込みがない場合の小加振と大加振入力の時は, 地表面に対して建物上部の加速度最大值は増幅されていないが，そ れよりも入力が大きい場合には増幅されている。これは基礎の過度 の寸べりや浮き上がりが生じ応答最大值が大きくなったものと考え られる。複合改良地盤（TR, HDR）を側面地盤とした場合には増 幅が小さく, Slip の場合では高減衰ゴムを用いた HDR で応答低減 が大きい。

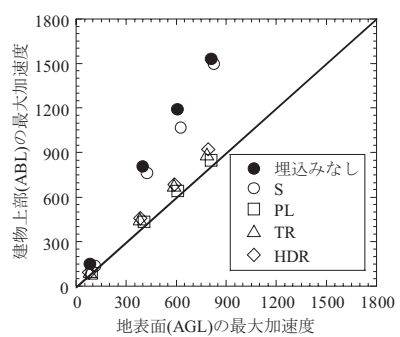

(a) Non-slip

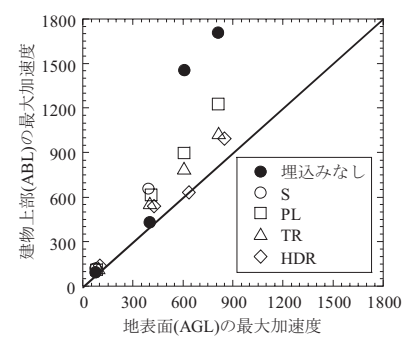

(b) Slip
図 6 加速度最大值の比較 


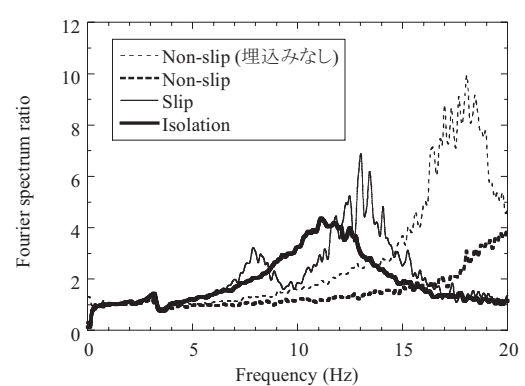

(a) PL，小加振

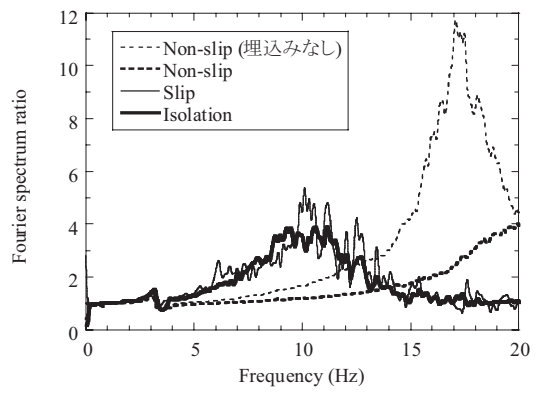

(a') PL, 大加振

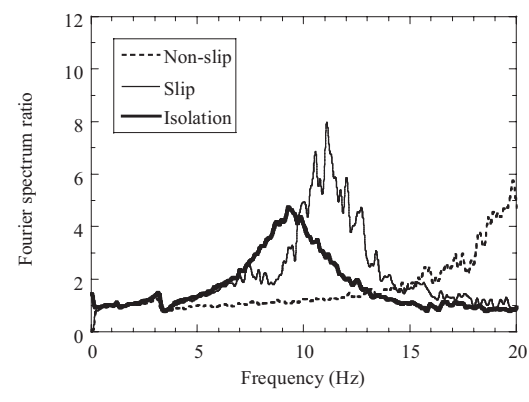

(b) $\mathrm{TR}$, 小加振

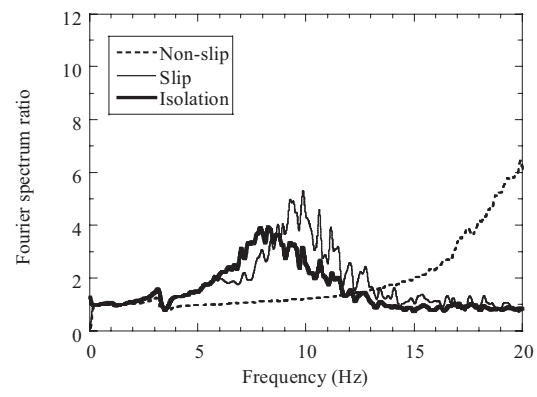

(b') TR, 大加振

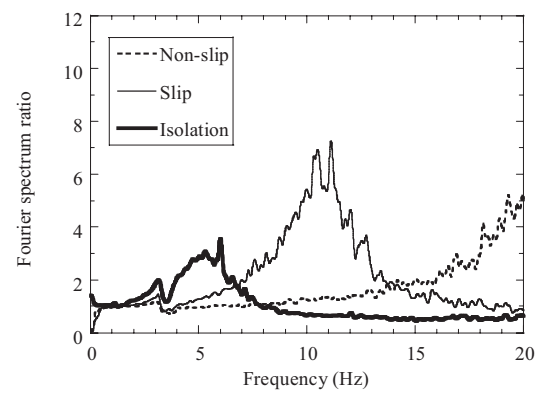

(c) HDR, 小加振

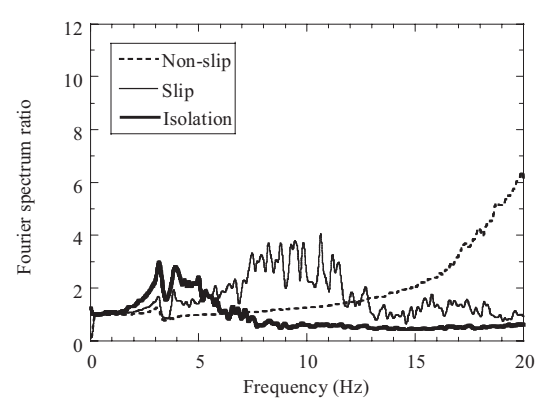

(c') HDR, 大加振

図 7 基礎底面と支持地盤の接触条件によるフーリエスペクトル比の比較（ABL/AGL）（剛体モデル）

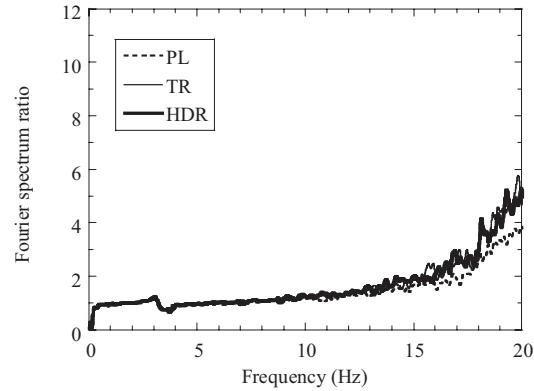

(a) Non-slip, 小加振

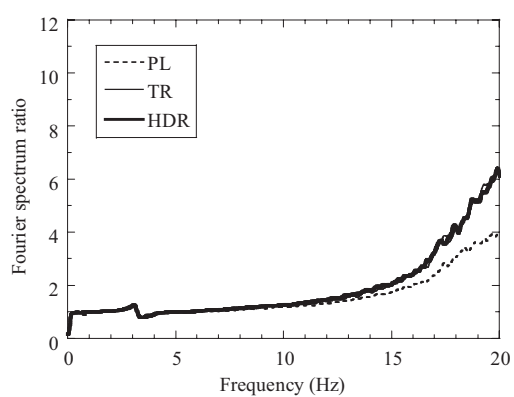

(a') Non-slip, 大加振

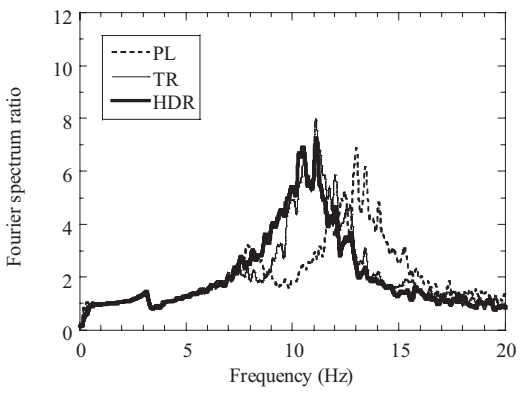

(b) Slip, 小加振

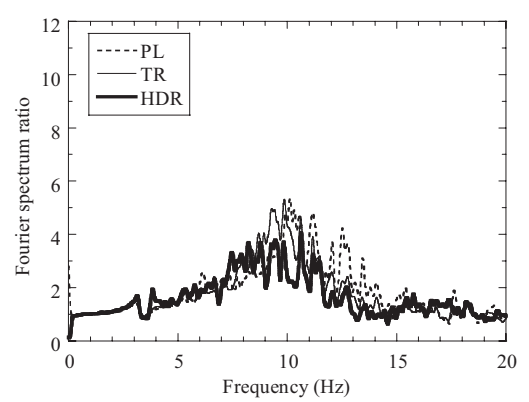

(b') Slip, 大加振

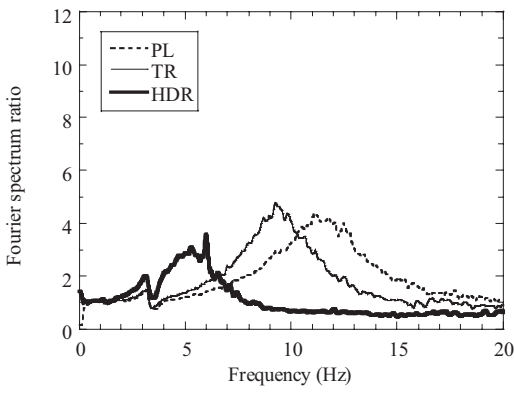

(c) Isolation, 小加振

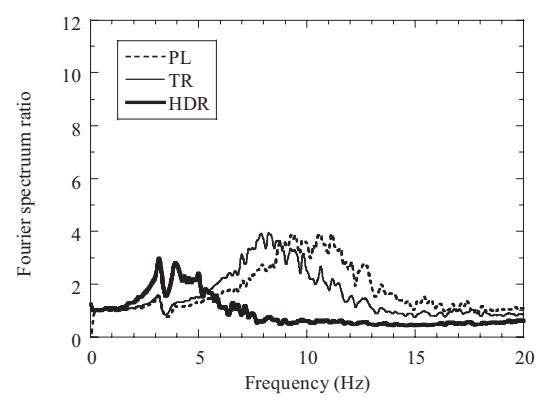

(c') Isolation, 大加振

図 8 基礎側面埋土地盤の違いによるフーリエスペクトル比の比較（ABL/AGL）（剛体モデル）

\section{（2）基礎底面の接触条件と側面地盤の違いによる比較}

地震動入力時 (小加振, 大加振) に計測された，地表面に対する 剛体モデルの建物上部の加速度フーリエスペクトル比（ABL/AGL） を比較した。接触条件としては, 接着あり (Non-slip), 接着なし (Slip), 絶縁 (Isolation) の 3 種類である。ここでは, 基礎側面地 盤がセメント系改良地盤（PL）, 複合改良地盤（TR, HDR）のケ 一スを図 7 に示寸。図 7(a) と (a')には Non-slip で埋込みがない場合
の結果も比較して示す。また, 側面地盤がセメント系改良地盤 $(\mathrm{PL})$ と 2 種類の複合改良地盤（TR, HDR）の 3 ケースで, 基礎底面と 支持地盤の接触条件が, 接着あり (Non-slip), 接着なし（Slip）, 絶縁（Isolation）の場合を図 8 に示す。なお，図では最大振動数を $20 \mathrm{~Hz}$ としているが，これは振動台の加振性能限界が $20 \mathrm{~Hz}$ （実際の 振動数で $200 \mathrm{~Hz}$ ) であるためである。

まず, 埋込みがない場合の結果に比べ, 側面の改良地盤の効果は 
応答振幅を低減すること, 地盤との連成系のピーク振動数が Non-slip の条件では高振動数側となるが, 基礎底面の接触条件によ り低振動数側に移行することが確認できる。

埋土地盤がある全てのケースにおいて, 連成系のピーク振動数は Non-slip, Slip, Isolation の順で小さくなる。また, 最大振幅は, Slip に比べ Isolation で小さくなる。Non-slip の場合は, PL の振幅 が小さくなる。Slip と Isolation の最大振幅は入力レベルが大きく なると小さくなり，その傾向は PL，TR，HDR の順で大きい。ま た，側面改良地盤の剛性の違いにより，ピーク振動数が PL，TR， HDR の順に低振動数側に移行している。このように, 大地震時に 建物応答を低減する方法として, 基礎底面と支持地盤間の摩擦抵抗 を小さくして入力動を低減するとともに, 勒性のある側面改良地盤 との非線形相互作用の効果により, 側面地盤でのエネルギー吸収を 大きくすることが有効であることがわかる。

\section{（3）建物モデルの違いによる比較}

次に, 建物モデルの違いとして図 9 に板ばねモデルの大加振入力 時の結果を示す。側面地盤が PL に比べ HDR の方が最大振幅が小

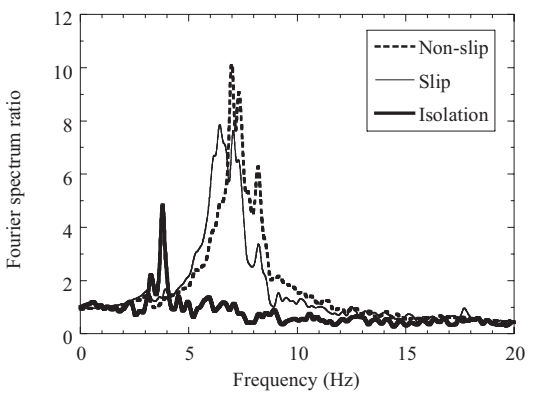

(a) PL，大加振

図 9 基礎底面と支持地盤の接触条件によるフーリエスペクトル比の比較

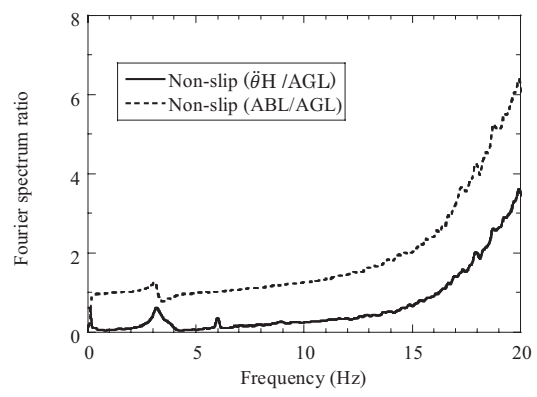

(a) Non-slip

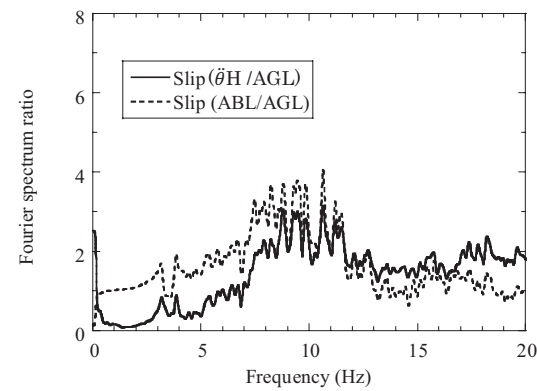

(b) Slip
さくなることが確認できるが，板ばねモデルは剛体モデルに比べて 側面地盤による効果が小さく, Non-slip と Slip では板ばねモデル の基礎固定時の固有振動数付近で卓越振動数となる。なお，全ての 図の $3 \mathrm{~Hz}$ 付近に振幅の変化が見られるが, これは振動台のピッチン グ振動の影響で回転入力が生じたためである。

\section{（4）建物のロッキング振動による影響}

ここでは，大加振時の建物のロッキング振動の影響を検討する。 まず，図 3(b)に示した基礎部両端の二つの鉛直加速度の差を基礎幅 $0.08 \mathrm{~m}$ で除して求めた建物の角加速度 $\ddot{\theta}\left(\mathrm{rad} / \mathrm{s}^{2}\right)$ に建物高さ $\mathrm{H}(\mathrm{m})$ を乗じることにより，ロッキング振動成分による建物上部の水平加 速度 $\ddot{\theta} \mathrm{H}\left(\mathrm{m} / \mathrm{s}^{2}\right)$ を求めた。そして, 地表面の加速度に対するフーリ エスペクトル比（肖 $\mathrm{H} / \mathrm{AGL})$ を，基礎底面と支持地盤の接触条件の 違い，基礎側面埋土地盤の違いにより比較検討した。

図 10 に基礎側面埋土地盤が HDR のケースでの大加振時のフーリ エスペクトル比 ( $\ddot{\theta} \mathrm{H} / \mathrm{AGL})$ を, 接触条件ごとに示す。また, 図 7(C') で示した同ケースの建物上部で計測された水平加速度の地表面に対 するフーリエスペクトル比（ABL/AGL）も併せて示す。

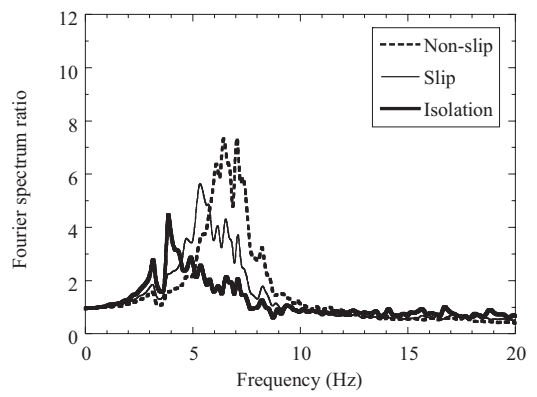

(c) HDR, 大加振

（ABL/AGL）（板ばねモデル）

図 10 フーリエスペクトル比 $(\ddot{\theta} \mathrm{H} / \mathrm{AGL}), \mathrm{HDR}$, 大加振

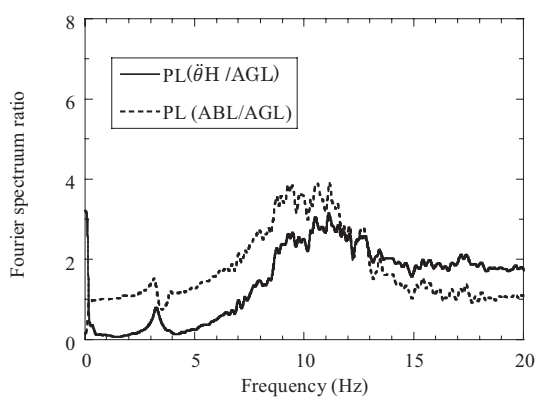

(a) PL

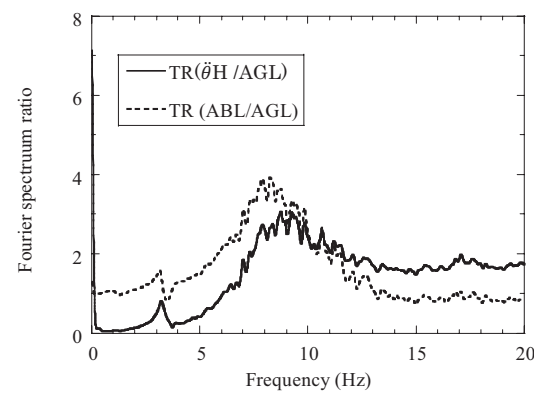

(b) TR

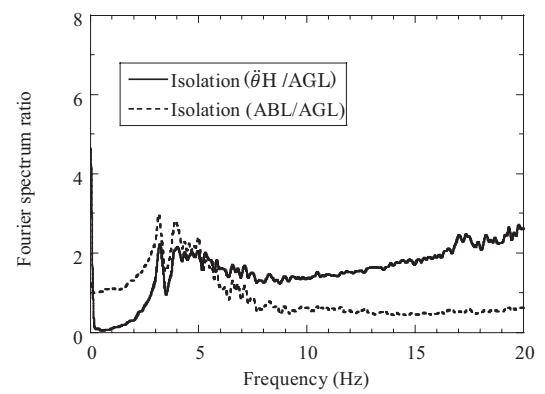

(c) Isolation

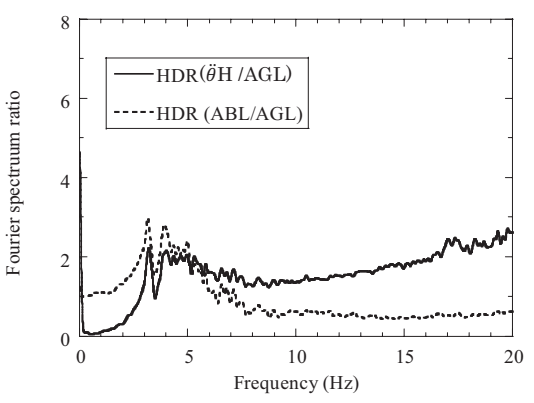

(c) HDR

図 11 フーリエスペクトル比 $(\ddot{\theta} \mathrm{H} / \mathrm{AGL})$, Isolation, 大加振 


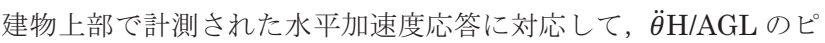
一ク振動数も Non-slip, Slip, Isolation の順に小さくなる。また, 建物応答に占めるロッキング成分の割合は, Non-slip では加振振動 数範囲ではほぼ一定であるが, Slip と Isolation の場合はピーク振 動数付近で最大となり, それ以降の高振動数域でもその割合は大き くなる。これは, 建物の水平応答が建物上部と基礎部で逆位相とな る振動モードを呈しているためである。

図 11 に基礎底面の接触条件が Isolation の場合での大加振時のフ ーリエスペクトル比（光H / AGL）を，側面埋土地盤の各種類につい て示す。また, 同ケースの建物上部で計測された水平加速度の地表 面に対するフーリエスペクトル比 (ABL/AGL) も併せて示す。建 物上部で計測された水平応答のピーク振動数付近におけるロッキン グ成分の割合は PL，TR，HDR とも大きくなる。これより，基礎 底面を絶縁した場合には水平応答が著しく低減すること, その水平 応答は建物のロッキングに起因する応答成分であることがわかる。 なお，基礎底面を絶縁した場合（Isolation）で埋土地盤が HDR の ケースのピーク付近の応答性状が複雑に変化しているのは, 前述し た振動台のピッチング振動と重なっているためである。

\section{3 次元有限要素法による地震応答解析}

振動台実験のシミュレーション解析を $3 \mathrm{D}$ 非線形 $\mathrm{FEM}^{15}$ )を用いて 行い, 建物の応答性状についてさらに検討する。ここでは, 3 章で 行った実験のうち, 剛体モデルにおいて, 基礎側面地盤が複合改良 地盤（HDR）で，基礎底面と支持地盤の接触条件が接着あり

(Non-slip), 絶縁 (Isolation) の大加振時についてシミュレーショ ン解析を行った。

\section{1. 解析モデル}

図 12 に FEM 解析モデルの平面図と断面図を示す。断面図中の $\nabla$ 印で示す 4 箇所の節点をそれぞれ地盤深部・地表面・基礎部・建物 上部として水平方向の加速度を求めた。また 印で示す 2 箇所で建 物基䃈部の鉛直方向の加速度を求めた。基䃈側面地盤と基礎部は寸 ベりと剥離を考慮した接触条件を用い, 摩擦係数は小さいとして 0.05 とした。基礎底面が接着ありの場合では, 基礎底面と支持地盤 を節点共有により密着させた。図 13 に基䃈底面が絶縁の場合での 基礎周辺地盤の詳細図を示す。実験では基䃈底面と支持地盤の間に 磁石を設置して $10 \mathrm{~mm}$ 絶縁させた。解析では磁石による基礎と支持 地盤との間の回転反力を回転ばねにモデル化して, 絶縁状態を模擬 した。回転ばねの值は, 使用した磁石の物性よりクーロンの式で磁 荷を求めて，K=1890N・m/rad とした。

本解析で使用した各諸元を表 4 に示す。鋼製土槽と建物模型（基 礎下部, 基礎上部, 柱, 建物上部）は全て剛体でモデル化し, 実験 時と同じ重さになるように設定した。また, 支持地盤は弾性体で, 埋土地盤は Mohr-Coulomb モデルで弾塑性体としてモデル化した。 支持地盤の物性值については, 材料試験の結果をもとにして, 基礎 側面埋込みなし・基礎底面接着ありの実験のシミュレーション解析 を行い，ヤング係数を調整した。図 14 に支持地盤のヤング係数を $\mathrm{E}=113 \mathrm{~N} / \mathrm{mm}^{2}$ とした際の解析と実験によるフーリエスペクトル比 を比較して示すが, 両結果は良く対応している。また, 基礎側面埋 土地盤の物性值は, HDR 複合改良地盤の材料試験の結果を用いた。 地盤の減衰は質量比例型で 1 次固有振動数に対して $5 \%$ とした。

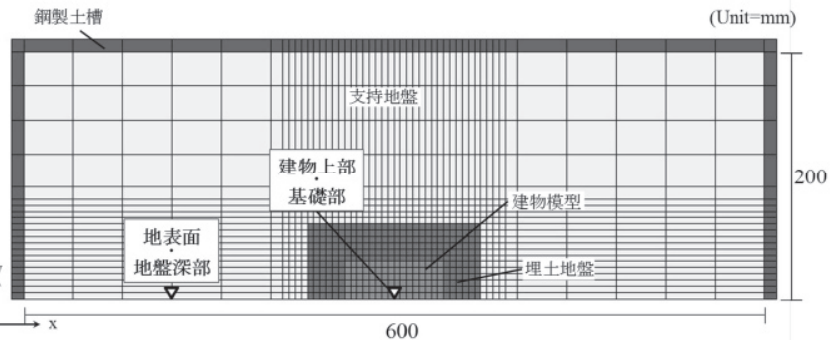

(a) 平面図

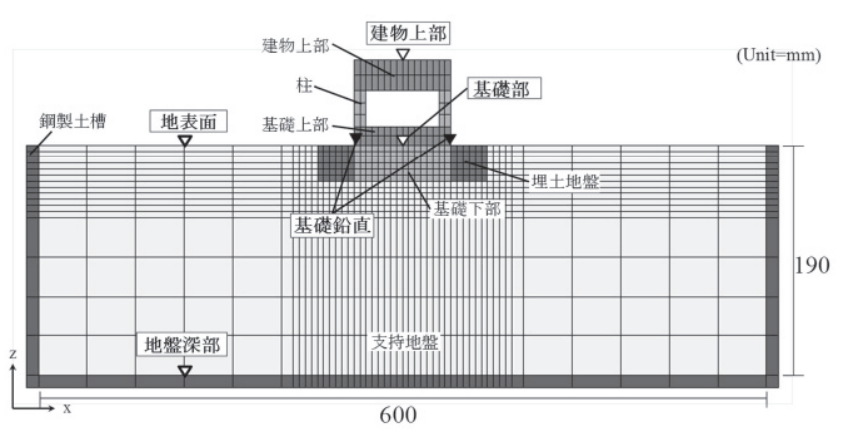

(b) 断面図

図 12 解析モデル $(1 / 2$ モデル $)$

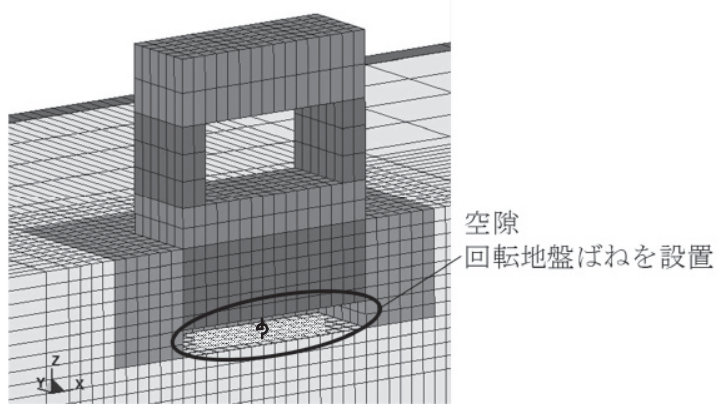

図 13 絶縁時の基礎周辺地盤の詳細図 (1/2 モデル)

表 4 解析の諸元

\begin{tabular}{|c|c|c|c|c|c|c|}
\hline & $\begin{array}{c}\text { 密度 } \\
\left(\mathrm{g} / \mathrm{cm}^{3}\right)\end{array}$ & $\begin{array}{c}\text { ヤング倸数 } \\
\left(\mathrm{N} / \mathrm{mm}^{2}\right)\end{array}$ & $\begin{array}{c}\text { ポアソン } \\
\text { 比 }\end{array}$ & $\begin{array}{c}\text { 内部摩擦角 } \\
\left({ }^{\circ}\right)\end{array}$ & $\begin{array}{l}\text { 粘着力 } \\
\left(\mathrm{N} / \mathrm{mm}^{2}\right)\end{array}$ & 材料モデル \\
\hline 建物モデル & 8.4 & $1.26 \times 10^{5}$ & 0.3 & ${ }^{2}$ & $\mathrm{X}^{2}$ & 剛体 \\
\hline 柱 & 0.11 & $2.05 \times 10^{5}$ & 0.3 & . & 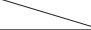 & 剛体 \\
\hline 基礎上部 & 4.81 & $2.05 \times 10^{5}$ & 0.3 & - & $\mathrm{X}_{2}$ & 剛体 \\
\hline 基䃈下部 & 2.4 & $6.93 \times 10^{4}$ & 0.3 & $\mathrm{~N}$ & - & 剛体 \\
\hline 高減衰(HDR) & 1.38 & 63 & 0.45 & 22 & 0.1 & 弾塑性体 \\
\hline 支持地盤 & 1.55 & 113 & 0.45 & $\gamma_{1}$ & 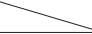 & 弾性体 \\
\hline 鋼製土槽 & 7.87 & $205 \times 10^{5}$ & 0.3 & $x_{0}$ & 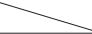 & 剛体 \\
\hline
\end{tabular}

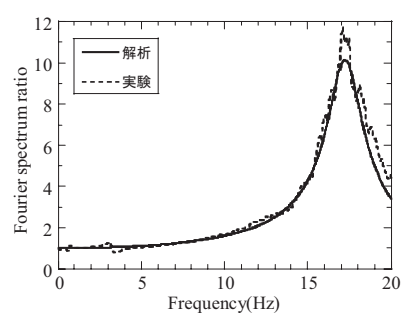

図 14 地表面に対する建物上部のフーリエスペクトル比 (埋込みなし・接着あり・大加振) 


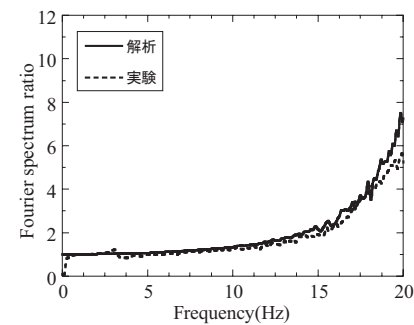

(a) Non-slip

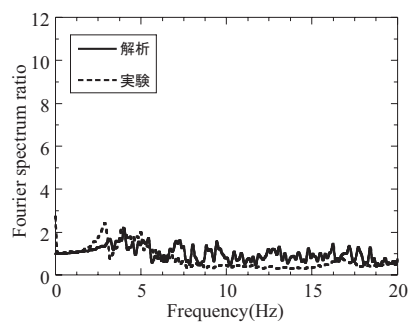

(b) Isolation
図 15 地表面に対する建物上部の水平方向のフーリエスペクトル比

$(\mathrm{HDR} \cdot$ 大加振 $)$

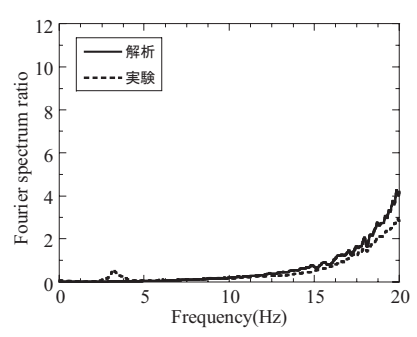

(a) Non-slip

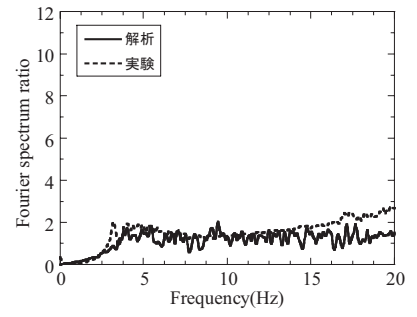

(b) Isolation
図 16 地表面に対する建物上部の回転成分のフーリエスペクトル比 $(\mathrm{HDR} \cdot$ 大加振 $)$

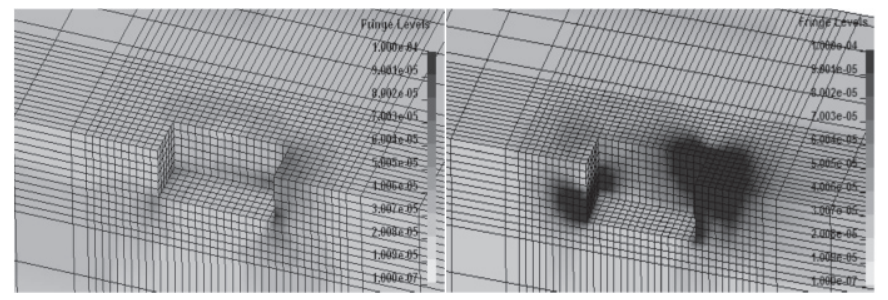

最大值 $1.21 \times 10^{-2}(\%)$

(a) Non-slip

図 17 最大主ひずみ分布
最大值 $8.48 \times 10^{-2}(\%)$

(b) Isolation
(HDR · 大加振)

\section{2. 解析結果}

図 15 に, 地表面に対する建物上部の水平方向のフーリエスペク トル比を(a)Non-slip, (b)Isolation の場合について実験と解析を比 較して示す。両結果の実験と解析は良く対応しており, 基礎底面の 接触条件の違いによる応答特性を捉えている。次に建物上部での口 ッキング成分の比較を図 16 に示す。両接触条件とも実験と解析は 良く対応しており，3D 非線形 FEM の解析により基礎側面が HDR 地盤で, 基礎底面の接触条件が接着ありと絶縁の場合の建物の応答 性状をシミュレーションできた。

ここで, 実験時の建物上部での水平加速度応答が最大值に近い時 刻における(a)Non-slip, (b)Isolationの場合の最大主ひずみ分布を, 最大值と併せて図 17 に示す。接着ありに比べて絶縁では振動方向 の前後面の埋土地盤でのひずみが大きくなっている。さらに, 基礎 底面を絶縁した場合に, 側面地盤からの入力により生じた建物の口 ッキング振動によって, 基礎前面の埋土地盤上部と後面での埋土地 盤下部の両面で震動エネルギーを吸収し応答を低減していることが わかる。

\section{5. まとめ}

本研究では，基礎側面地盤に用いる新しく開発した複合改良地盤 の地盤物性を室内試験により把握した。さらに，直接基礎の底面接 触条件と本材料を基礎側面の埋土地盤へ適用した場合の地震応答低 減効果を振動台模型実験により検討した。また，3D 非線形 FEM を 用いた解析検討により, 複合改良地盤を用いた基礎の地震応答低減 効果について検討を行った。以下に得られた知見を示す。

1）ゴムチップと繊維材を添加した複合改良地盤の一軸圧縮試験で は，セメント系改良地盤（PL）は破壊ひずみが $1 \%$ 程度であるのに 対して, 複合改良地盤（TR, HDR）は破壊ひずみが $7.5 \%$ 程と増加 し，ピーク強度を示した後も強度低下が小さく，15\%以上の変形に 対しても形状を保持し勒性の向上が確認できた。また，繰返しせん 断試験では, TR, HDR は PL と比べてせん断剛性は小さく, 大ひ

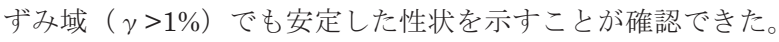

2）直接基礎の側面をセメント系改良地盤（PL）と複合改良地盤 （TR，HDR）で埋込んだ建物模型の振動台実験では，地盤一建物 連成系のピーク振動数は, 基礎底面の接触条件が接着あり, 接着な し, 絶縁の順で小さくなり, 最大振幅は絶縁の条件で低減効果が大 きい。また, 接触条件が接着なしと絶縁の場合の最大振幅は入力レ ベルが大きくなると小さくなり, HDR の複合改良地盤でひずみ依 存による応答低減効果が大きいことが確認できた。

3） 3D 非線形 FEM を用いた解析では, 基礎底面が接着ありと絶縁 の接触条件で, 基礎側面が HDR 複合改良地盤の建物応答性状の違 いを良く捉えることができた。また，HDR 側面地盤の最大主ひず み分布より，基礎底面が接着ありよりも絶縁の場合で，建物のロッ キング振動による基礎前後面の複合改良地盤の塑性化によって震動 エネルギーを吸収し，建物応答を低減することが確認できた。

4）以上から，基礎底面の摩擦抵抗を小さくして入力動の低減と非 （避）共振化を図り，基礎側面の複合改良地盤で震動エネルギーを 吸収することにより建物の地震応答を大幅に低減できる。さらに, 勒性のある複合改良地盤は, 大地震時においても埋込みによる応答 低減効果と基礎の過度の変形を抑制することが期待できる。一方, 基礎底面を絶縁させた条件では，建物の形状によってはロッキング 成分が卓越するため, 上下動応答を含め対策が必要となる。

今後，実大建物への適用に向けて，建物モデルの振動特性や入力 地震動の特性による応答低減効果や、基礎の絶縁方法についてさら に研究を進める予定である。

\section{謝辞}

本研究の一部は, 平成 23 年度科学研究費補助金[基盤研究(B) 極 大地震入力に対する高耐震基礎の開発と入力機構の解明に関する研 究(22360226)]の助成により実施しました。また，複合改良地盤を作 製するにあたり，住友ゴム工業株式会社より高減衰ゴムをご提供い ただきました。付記して，謝意を表します。

\section{参考文献}

1）日本建築学会 : 建物と地盤の動的相互作用を考慮した応答解析と耐震設 計, 2006.2 .

2）日本建築学会，基礎構造系振動小委員会：第 8 回構造物と地盤の動的相 互作用シンポジウムー非線形相互作用の解明と設計への組み込み一, 2006.12 . 
3）壁谷澤寿一, 壁谷澤寿梅 : 基礎滑り挙動を伴う直接基礎建物の地震応答 推定手法, 日本建築学会構造系論文集, 第 634 号, pp.2151-2158, 2008.12.

4) 日本建築センター: 改訂版 建築物のための改良地盤の設計及び品質管理 指針, 2002 .

5）島村淳，岸本美季，柏尚稔，宮本裕司：ゴムチップと繊維材を用いた複 合地盤材料の力学特性に関する研究, 日本建築学会技術報告集, 第 17 巻, 第 35 号, pp.61-66, 2011.2.

6) 宮本裕司, 島村淳, 古山田耕司, 見坊東光, 山添正稔 : ゴムチップと繊 維補強材を用いた複合地盤の非線形相互作用と応答低減(その 1 2), 日本 建築学会大会学術講演梗概集, 構造 II , pp.29-32, 2008.9.

7）廣田昌憲, 石村紀久雄, 鈴木康嗣, 三浦賢治, 永野正行, 清田芳治 : 地 震応答低減地業の開発, その 1 解析的検討と材料試験, 日本建築学会構 造系論文集，第 448 号, pp.37-46, 1993.6.

8）鈴木康嗣, 廣田昌憲, 石村紀久雄, 三浦賢治, 清田芳治 : 地震応答低減 地業の開発, その 2 高減衰材料の動的変形特性, 日本建築学会構造系論 文集，第 458 号，pp.29-38，1994.4.

9）岸本美季, 宮本裕司：三次元有限要素解析による地盤一構造物系の地震
応答性状に関寸る研究, 日本建築学会近畿支部研究報告集構造系, pp.5-8, 2009.6 .

10) Atsushi Shimamura, Hisatoshi Kashiwa, Yuji Miyamoto : Earthquake Response Reduction Considering Nonlinear Interaction between Composite Geomaterials and Foundation, ASEM'11 ${ }^{+}$(Seoul), pp.4972-4981，2011.9

11）地盤工学会：土質試験の方法と解説， 2000 .

12) Akio Hara, Yoshiharu Kiyota : Dynamic Shear Tests of Soils for Seismic Analysis, 9 th $^{\text {th }}$ MFE (Tokyo), Vol. 2, pp.247-250, 1977.

13）日本建築学会：入門・建物と地盤の動的相互作用, 1996.4 .

14）江守一郎，D.J. シューリング：模型実験の理論と応用，技報堂出版, 1981.

15）日本総合研究所エンジニアリング事業本部：LS-DYNA 使用手引き Second Edition, 2004.5.

（2013年 5 月10日原稿受理，2013年 6 月14日採用決定） 